\title{
Impact of two or three daily subcutaneous injections of hexarelin, a synthetic growth hormone (GH) secretagogue, on 24-h GH, prolactin, adrenocorticotropin and cortisol secretion in humans
}

\author{
Mauro Maccario, Johannes D Veldhuis ${ }^{1}$, Fabio Broglio, Lidia Di Vito, Emanuela Arvat, Romano Deghenghi ${ }^{2}$ and \\ Ezio Ghigo \\ Division of Endocrinology, Department of Internal Medicine, University of Turin, Turin, Italy, ${ }^{1}$ Division of Endocrinology, University of Virgina, \\ Charlottesville, Virginia, USA and ${ }^{2}$ Europeptides, Argenteuil, France
}

(Correspondence should be addressed to M Maccario, Divisione di Endocrinologia, Ospedale Molinette, C.so Dogliotti 14, 10126 Torino, Italy; Email: mauromac@interfree.it)

\begin{abstract}
Objective: To extend the insights on the action of GH secretagogues (GHS) on pituitary function, we studied the impact of intermittent daily s.c. administration of a peptidyl GHS, hexarelin (HEX), on 24-h GH, PRL, ACTH and cortisol release in healthy volunteers.

Design: We investigated the impact of two or three times daily s.c. administration of a short-acting peptidyl GHS, the hexapeptide HEX $(1.5 \mu \mathrm{g} / \mathrm{kg})$ on $24-\mathrm{h}$ GH, PRL, ACTH and cortisol secretion (sampling every $20 \mathrm{~min}$ ) in six normal young men. To monitor possible down-regulation, the effect of $1 \mu \mathrm{g} / \mathrm{kg}$ i.v. HEX at the end of each 24-h sampling period was studied.

Methods: Multi-parameter deconvolution analysis was used to quantitate pulsatile GH, PRL, ACTH and cortisol secretion and estimate the corresponding hormone half-lives. Complementary to deconvolution analysis, approximate entropy was used as a scale- and model-independent statistic to quantify the serial orderliness or pattern regularity of hormone measurements.

Results: Mean and integrated (24-h) serum GH concentrations were increased from baseline values to the same extent by two and three HEX injections. Both HEX schedules equally increased GH secretory burst mass (but not burst frequency), mean daily GH production rate, GH half-life and irregularity of GH release patterns. No change occurred in the secretion of IGF-I, PRL, ACTH and cortisol. Intravenous HEX at the end of each spontaneous 24-h profile induced a significant rise in GH, PRL, ACTH and cortisol. Prior HEX administration blunted the GH response, abolished that of ACTH and cortisol and did not modify the PRL increase.

Conclusions: The study showed that two or three daily s.c. injections of HEX augmented 24-h GH secretion equally, amplifying selectively GH secretory pulse mass without altering lactotroph and corticotroph secretion. IGF-I levels were not modified by these 1-day HEX treatment schedules.
\end{abstract}

European Journal of Endocrinology 146 311-318

\section{Introduction}

The neuroendocrine control of pulsatile somatotroph secretion is mediated by hypothalamic signals, intrapituitary mechanisms and multilevel feedback effects $(1-3)$. The interplay between growth hormonereleasing hormone (GHRH) and somatostatin has a major role in the neural control of growth hormone (GH) secretion. In addition, GH secretion is subject to important influences by neurotransmitters, peripheral hormones and metabolic fuels, and possibly the natural ligand of the GH secretagogue (GHS) receptor (GHS-R) (2, 3). The last-mentioned family of agonists was discovered based on studies of synthetic peptidyl and non-peptidyl GHS (4-6). A natural ligand of the GHS-R, ghrelin, was recently purified from the stomach as a 28 amino acid peptide with a unique n-octanoyl esterification of the third serine residue (4). Ghrelin exerts potent stimulatory effects on somatotroph secretion, and is expressed in the brain and is measurable in the blood of rodents and the human $(7,8)$. The activity of ghrelin as well as that of non-natural GHS is not fully specific for GH; in fact, most GHSs also stimulate lactotroph and corticotroph secretion acutely $(1,5,9)$.

Non-natural peptidyl and non-peptidyl GHSs can induce marked $\mathrm{GH}$ release after oral administration 
$(5,6,9)$, and thus have received attention in recent years as potential alternatives to restore the activity of the GH/insulin-like growth factor-I (IGF-I) axis in various states of GH insufficiency $(9-11)$, especially in conditions like the somatopause, which could reflect reduced activity of an endogenous GHS-R ligand (12, 13). GHSs act mainly at the hypothalamic level by eliciting GHRH release and functionally antagonizing somatostatin's action $(14,15)$. The GH-releasing effect in the adult is generally independent of gender, but exhibits age-related variations $(16,17)$.

GHSs augment both basal non-pulsatile GH release and $\mathrm{GH}$ pulse mass, and increase the irregularity of 24-h GH secretion without changing GH pulse duration, interpulse interval, frequency or half-life $(14,15,18)$. More prolonged administration elevates circulating IGF-I levels (19-21). The latter response could contribute to the progressive reduction of the stimulatory effects of GHS during chronic administration $(22,23)$. In addition, acute GHS infusion can induce homologous desensitization in humans as well as other animals $(14,23-28)$. Thus, the actions of GHS on somatotroph secretion may be influenced by intermittent versus continuous administration, as well as the pharmacokinetics of different molecules $(19-21,29,30)$. Peptidyl GHSs have short-lasting effects, whereas a non-peptidyl GHS, MK-0677, possesses high bioavailability and exerts long-lasting effects $(20,31,32)$. Single daily oral administration of MK-0677 increases activity of the GH/IGF-I axis, whereas recurrent administration of peptidyl GHSs or, alternatively, continuous parenteral infusion might be needed to achieve the same effect $(9,20)$.

In the present study, we evaluated the impact of two or three daily injections of a peptidyl GHS, namely the hexapeptide, hexarelin (HEX), on 24-h somatotroph, lactotroph and corticotroph secretion in normal young volunteers. We applied two complementary technical strategies to appraise the dynamic regulation of somatotropic secretion: (a) deconvolution analysis to estimate underlying rates of pulsatile $\mathrm{GH}$ secretion and half-life from plasma $\mathrm{GH}$ concentration profiles (33) and (b) approximate entropy (ApEn) to quantify the regularity or orderliness of GH secretion $(34,35)$. Concurrently, we evaluated possible down-regulation of $\mathrm{GH}$, prolactin (PRL) and adrenocorticotropin (ACTH) secretory responses to the twice- and three-times daily scheduled GHS administration.

\section{Subjects and methods}

Six healthy young male volunteers (age (means \pm S.E.M.): $30 \pm 1.2$ years, range $27-35$ years) were studied after providing written and voluntary informed consent. The study protocol had been approved by an independent local ethical committee.

\section{Study design}

All subjects were studied in three different sessions in a randomly assigned order with a wash-out period of at least 3 days. Volunteers were admitted to the Clinical Unit on the morning of the test session following an overnight fast. The cubital veins were cannulated at $0730 \mathrm{~h}$ and kept patent over $24 \mathrm{~h}$ by slow infusion of isotonic saline. During the day, subjects received a $200 \mathrm{kcal}$ breakfast $(60 \%$ carbohydrate) at $0900 \mathrm{~h}$ and a $800 \mathrm{kcal}(50 \%$ carbohydrate, $30 \%$ lipid, $20 \%$ protein) lunch and dinner at $1300 \mathrm{~h}$ and $2000 \mathrm{~h}$ respectively.

At $0800,1600,2000$ and $2400 \mathrm{~h}$ subjects received either $1 \mathrm{ml}$ saline or HEX $(1.5 \mu \mathrm{g} / \mathrm{kg}$ s.c.; $100 \mu \mathrm{g}$ per vial; Europeptides, Argenteuil, France) according to the following schema. (A) HEX at 0800 and $2000 \mathrm{~h}$; saline at 1600 and $2400 \mathrm{~h}$. (B) HEX at 0800, 1600 and $2400 \mathrm{~h}$; saline at $2000 \mathrm{~h}$. (C) Saline alone. At the end of each session (i.e. at $0800 \mathrm{~h}$ on the following day), all subjects received HEX $(1 \mu \mathrm{g} / \mathrm{kg}$ as an i.v. bolus).

Blood samples were withdrawn every $20 \mathrm{~min}$ for $26 \mathrm{~h}$ from 0800 on day 1 to $1000 \mathrm{~h}$ on the following day. GH, PRL, ACTH and cortisol were assayed in each sample (see below).

\section{Hormone assays}

Serum GH concentrations $(\mu \mathrm{g} / \mathrm{l})$ were measured by immunoradiometric assay (hGH-CTK; Sorin Biomedica, Saluggia, Italy). All samples from an individual subject were analyzed together in duplicate. The sensitivity of the assay was $0.15 \mu \mathrm{g} / \mathrm{l}$. The ranges of inter- and intra-assay coefficients of variation were $4.9-6.5 \%$ and $1.5-2.9 \%$ respectively.

Serum PRL levels $(\mu \mathrm{g} / \mathrm{l})$ were measured by immunoradiometric assay (PROLCTK; Sorin Biomedica), as above. The sensitivity of the assay was $0.45 \mu \mathrm{g} / \mathrm{l}$. The ranges of inter- and intra-assay coefficients of variation were $7.7-10.8 \%$ and $2.4-3.4 \%$ respectively.

Plasma ACTH levels (ng/l) were measured by immunoradiometric assay (ACTH; Nichols Institute Diagnostic, San Juan Capistrano, CA, USA). The sensitivity of the assay was $1 \mathrm{ng} / \mathrm{l}$. The ranges of inter- and intra-assay coefficients of variation were $2.4-8.5 \%$ and $3.9-$ 9.9\% respectively.

Cortisol (nmol/l) was measured by radioimmunoassay (CORT-CTK125; Diasorin Diagnostic, Saluggia, Italy). The sensitivity of the assay was $0.66 \mathrm{nmol} / \mathrm{l}$. The inter- and intra-assay coefficients of variation ranged from 4.3 to $14.6 \%$ and from 4.2 to $8.96 \%$ respectively.

\section{Data analysis}

Multiparameter deconvolution analysis was used to quantitate pulsatile GH, PRL, ACTH and cortisol secretion and estimate the corresponding hormone 
half-lives (36). Basal hormone secretion represents the calculated time-invariant interpulse component of the release profile. The daily pulsatile production rate is the product of the number of secretory bursts and the mean mass of GH released per pulse. Secretory pulse identification required that secretory burst amplitudes and the basal secretion rate exceed zero by $95 \%$ statistical confidence. The analyst was blinded to the randomization scheme.

\section{Approximate entropy}

ApEn was used as a scale- and model-independent statistic, which is complementary to deconvolution analysis (34). ApEn quantifies the serial orderliness or pattern regularity of hormone measurements. Normalized ApEn parameters of $\mathrm{m}=1$ (series length) and $r=20 \%$ (threshold) of the intraseries S.D. were used, as previously validated for 24-h time series (37). This statistic is thus designated ApEn (1, 20\%). Increased ApEn (at equal series lengths and similar parameter values, as used here) indicates greater

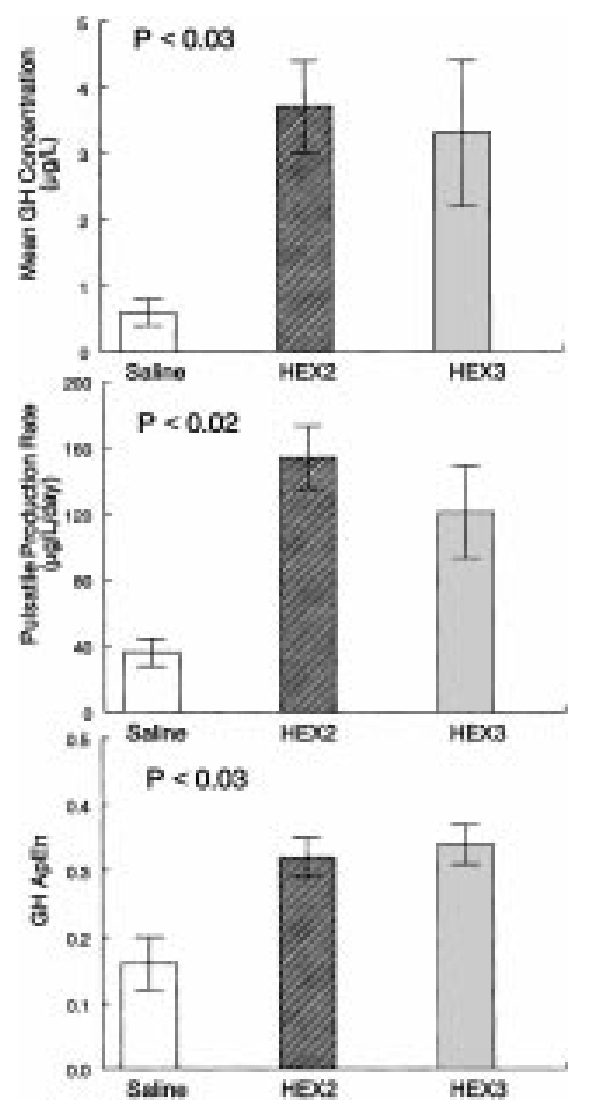

Figure 1 Mean GH concentration, pulsatile production rate and ApEn during saline or two (HEX2) or three (HEX3) daily s.c. injections of $1.5 \mu \mathrm{g} / \mathrm{kg}$ HEX in normal volunteers. Values are means \pm S.E.M. secretory process irregularity, consistent with altered within-axis feedforward feedback control (34).

The results are reported as the means \pm S.E.M. of absolute values as well as areas under curve (AUC) calculated by trapezoidal integration.

\section{Statistical analysis}

ANOVA with repeated measures was used to compare results among the different sessions. If a significant difference had occurred a post hoc analysis was carried out using Newman-Keuls test. $P<0.05$ was considered statistically significant.

\section{Results}

Mean and integrated (24-h) serum GH concentrations were increased $(P<0.03)$ from baseline values of $0.6 \pm 0.2 \mu \mathrm{g} / \mathrm{l}$ and $890 \pm 220 \mu \mathrm{g} / \mathrm{l}$ per min to the same extent by two and three HEX injections daily:

Table 1 Deconvolution analysis of repetitively sampled serum $\mathrm{GH}, \mathrm{PRL}, \mathrm{ACTH}$ and cortisol concentration profiles during saline or two (HEX2) or three (HEX3) HEX injections daily.

\begin{tabular}{|c|c|c|c|c|}
\hline & Saline & HEX2 & HEX3 & $P$ \\
\hline \multicolumn{5}{|c|}{ Basal secretion (concentration/day) } \\
\hline $\mathrm{GH}$ & $86 \pm 72$ & $29 \pm 14$ & $14 \pm 14$ & ns \\
\hline PRL & $1.4 \pm 14$ & $29 \pm 29$ & $14 \pm 1.4$ & ns \\
\hline ACTH & $245 \pm 29$ & $245 \pm 58$ & $216 \pm 86$ & ns \\
\hline Cortisol* $^{*}$ & 0 & 0 & 0 & - \\
\hline \multicolumn{5}{|c|}{ Mass (concentration units) } \\
\hline $\mathrm{GH}$ & $4.7 \pm 1.2$ & $23 \pm 3.3$ & $18 \pm 1.7$ & $<0.01$ \\
\hline PRL & $5.6 \pm 1.0$ & $4.4 \pm 0.6$ & $5.8 \pm 0.5$ & ns \\
\hline ACTH & $64 \pm 11.4$ & $44 \pm 16.7$ & $57 \pm 22.8$ & ns \\
\hline Cortisol & $154 \pm 13$ & $149 \pm 21$ & $182 \pm 25$ & ns \\
\hline \multicolumn{5}{|c|}{ Frequency (pulses/24h) } \\
\hline $\mathrm{GH}$ & $7.5 \pm 1.0$ & $7.0 \pm 0.6$ & $6.7 \pm 1.7$ & ns \\
\hline $\mathrm{PRL}$ & $13.1 \pm 0.7$ & $15.8 \pm 0.8$ & $12.5 \pm 1.0$ & ns \\
\hline ACTH & $17.2 \pm 1.0$ & $19.8 \pm 0.7$ & $18.5 \pm 1.1$ & ns \\
\hline Cortisol & $12.3 \pm 0.8$ & $11.7 \pm 0.7$ & $12.5 \pm 0.6$ & ns \\
\hline \multicolumn{5}{|c|}{ Pulsatile production rate ${ }^{\star \star *}$} \\
\hline $\mathrm{GH}$ & $36 \pm 8.3$ & $154 \pm 19.3$ & $121 \pm 28$ & $<0.01$ \\
\hline $\mathrm{PRL}$ & $68 \pm 9.5$ & $69 \pm 7.5$ & $73 \pm 9.3$ & ns \\
\hline ACTH & $1.1 \pm 0.2$ & $0.9 \pm 0.3$ & $1.1 \pm 0.5$ & ns \\
\hline Cortisol & $1.9 \pm 0.1$ & $1.7 \pm 0.3$ & $2.2 \pm 0.3$ & ns \\
\hline \multicolumn{5}{|c|}{ Mean concentration } \\
\hline $\mathrm{GH}$ & $0.6 \pm 0.2$ & $3.7 \pm 0.7$ & $3.3 \pm 1.1$ & $<0.03$ \\
\hline PRL & $5.6 \pm 0.7$ & $6.0 \pm 0.5$ & $6.1 \pm 0.9$ & ns \\
\hline ACTH & $19 \pm 2.3$ & $18 \pm 1.7$ & $18 \pm 1.4$ & ns \\
\hline Cortisol & $188 \pm 12$ & $173 \pm 11$ & $207 \pm 29$ & ns \\
\hline \multicolumn{5}{|c|}{ Integrated concentration** } \\
\hline $\mathrm{GH}$ & $0.9 \pm 0.2$ & $5.3 \pm 1.0$ & $4.3 \pm 1.2$ & $<0.02$ \\
\hline PRLs & $6.1 \pm 1.0$ & $8.5 \pm 0.7$ & $8.6 \pm 1.3$ & ns \\
\hline ACTH & $26 \pm 3.1$ & $25 \pm 2.4$ & $26 \pm 1.9$ & ns \\
\hline Cortisol & $265 \pm 18$ & $243 \pm 16$ & $248 \pm 58$ & ns \\
\hline
\end{tabular}

${ }^{*}$ Cortisol profiles were fit according to a model of zero basal secretion (see Methods).

${ }^{* *}$ Integrated concentration of $\mathrm{GH}$ and $\mathrm{PRL}$ are reported in $\mathrm{mg} / \mathrm{l}$ per min, $\mathrm{ACTH}$ in $\mathrm{ng} / \mathrm{l}$ per min and cortisol in $\mathrm{nmol} / \mathrm{l}$ per $\mathrm{min}$.

${ }^{* \star \star} \mathrm{GH}$ production rate is reported in $\mu \mathrm{g} / \mathrm{l}$ per day, $\mathrm{ACTH}$ in $\mathrm{ng} / \mathrm{l}$ per day and cortisol in $\mathrm{nmol} / \mathrm{l}$ per day.

ns, not significant. 
i.e. to $3.7 \pm 0.7$ vs $3.3 \pm 1.1 \mu \mathrm{g} / \mathrm{l}$ and $5300 \pm 1030$ vs $4300 \pm 1200 \mu \mathrm{g} / \mathrm{l}$ per min (Fig. 1).

Based on deconvolution analysis (Table 1), HEX augmented, to the same extent in response to two and three HEX treatments $(P<0.01)$, the daily pulsatile GH production rate by three- to fourfold and mean $\mathrm{GH}$ secretory burst mass from $4.7 \pm 1.2 \mu \mathrm{g} / \mathrm{l}$ at baseline to $23 \pm 3.3$ and $18 \pm 1.7 \mu \mathrm{g} / \mathrm{l}$ per min respectively. Pulse frequency did not change. $\mathrm{GH}$ half-life increased slightly from $15 \pm 0.8$ at baseline to $19 \pm 1.5$ and $22 \pm 1.9 \mathrm{~min}$ after two or three HEX administrations respectively $(P<0.05)$ (Figs 1 and 2$)$.

Both two and three HEX injections elevated ApEn values of the 24 -h $\mathrm{GH}$ profiles $(P<0.01)$ (Table 2 and Fig. 1).

GH peaks following the first two s.c. HEX stimuli were comparable, whereas that following the third injection was decreased.

Deconvolution analysis showed no changes in the parameters of PRL, ACTH and cortisol secretion after two or three HEX infusions. ApEn values of these hormones were also independent of intervention (Tables 1 and 2).

Cross (X)-ApEn analysis showed that there was a disjunction (i.e. synchronicity loss) of ACTH and cortisol secretion during two vs three daily HEX injections.

Acute challenge with i.v. HEX at the end of the spontaneous 24-h profile induced a marked GH rise (peak: $60 \pm 4.4 \mu \mathrm{g} / \mathrm{l}$ ) and a significant increase in
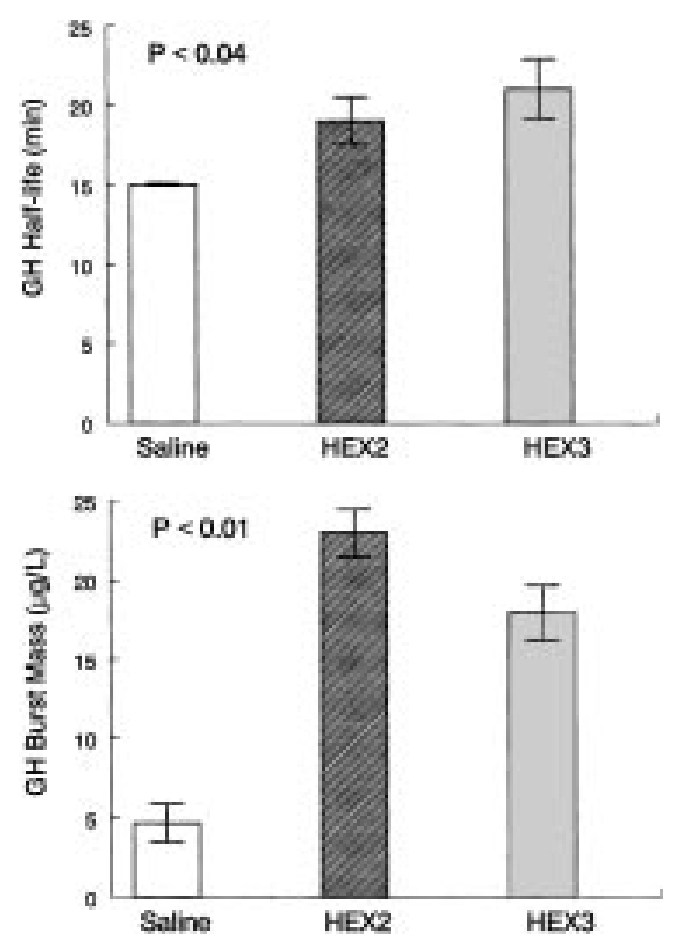

Figure $2 \mathrm{GH}$ half-life and burst mass during saline or two (HEX2) or three (HEX3) daily s.c. injections of $1.5 \mu \mathrm{g} / \mathrm{kg} \mathrm{HEX}$ in normal volunteers. Values are means \pm S.E.M. serum PRL $(13 \pm 1.9 \mu \mathrm{g} / \mathrm{l})$, ACTH $(77 \pm 7.7 \mathrm{ng} / \mathrm{l})$ and cortisol $(552 \pm 26 \mathrm{nmol} / \mathrm{l})$ concentrations (Table 3 and Fig. 3).

Two and three s.c. HEX administrations the day before blunted $(P<0.05)$ the $\mathrm{GH}$ response to acute i.v. HEX challenge to the same extent (peak: 39 and $35 \mu \mathrm{g} / \mathrm{l} ;$ AUC: $2.5 \pm 0.6$ and $2.1 \pm 0.5 \mathrm{mg} / \mathrm{l}$ per $\mathrm{min}$ ) when compared with the response recorded after 24-h saline administration (peak: $66 \mu \mathrm{g} / \mathrm{l}$; AUC: $4.4 \pm 0.4 \mathrm{mg} / \mathrm{l}$ per min). In addition, two and three s.c. HEX administrations abolished the ACTH and cortisol but did not modify the PRL response to the acute i.v. HEX challenge (Table 3 and Fig. 3).

Serum IGF-I concentrations at the end of the various testing sessions were similar.

\section{Side-effects}

No side-effects were evident after two or three s.c. injections of HEX daily. On the other hand, i.v. administration of HEX induced transient facial flushing in three subjects.

\section{Discussion}

The present study establishes the ability of two or three s.c. injections of a peptidyl GHS, HEX, to augment 24-h pulsatile GH secretion equivalently and significantly in young men. The increase in daily $\mathrm{GH}$ secretion driven by HEX reflected a preferential (three- to fourfold) increase in burst mass without any significant change in frequency. HEX also elevated the ApEn (irregularity) of $\mathrm{GH}$ pulsatility and blunted the $\mathrm{GH}$ response to a subsequent acute i.v. challenge with the hexapeptide at the end of $24 \mathrm{~h}$. Circulating total IGF-I levels did not change over this interval. Likewise, lactotroph and corticotroph secretion was not modified by either two or three s.c. injections of HEX. However, HEX pretreatment abolished the acute ACTH and cortisol (but not PRL) response to a delayed challenge with this hexapeptide.

In an earlier study in healthy older humans, continuous i.v. infusion of GH-releasing peptide-2 (GHRP2) also augmented 24-h serum GH concentrations due to an enhancement of the physiological pattern

Table 2 ApEn of GH, PRL, ACTH and cortisol profiles during saline or two (HEX2) or three (HEX3) HEX injections daily. Data are the means \pm S.E.M. $(n=6)$.

\begin{tabular}{lcccc}
\hline & Saline & HEX2 & HEX3 & $\boldsymbol{P}$ \\
\hline GH & $0.16 \pm 0.04$ & $0.32 \pm 0.03$ & $0.34 \pm 0.03$ & $<0.03$ \\
PRL & $1.01 \pm 0.07$ & $1.07 \pm 0.05$ & $1.09 \pm 0.04$ & ns \\
ACTH & $0.91 \pm 0.06$ & $1.05 \pm 0.07$ & $1.05 \pm 0.09$ & ns \\
Cortisol & $0.91 \pm 0.06$ & $0.96 \pm 0.03$ & $0.95 \pm 0.05$ & ns \\
\hline
\end{tabular}

ns, not significant. 
Table 3 Two-hour hormone release recorded at baseline (Basal, 2-h integrated (0800-1000 h) data from day 1 saline) and after acute challenge with i.v. HEX after each 24-h session (Saline, HEX2, HEX3). Data are the mean \pm S.E.M. $(n=6)$ integrated values.

\begin{tabular}{lllll}
\hline & Basal & Saline & HEX2 & HEX3 \\
\hline GH (mg/l per min) & $0.01 \pm 0.0$ & $4.4 \pm 0.4 \#$ & $2.5 \pm 0.6 \#^{*}$ & $2.1 \pm 0.5 \#^{*}$ \\
PRL (mg/l per min) & $0.4 \pm 0.1$ & $1.0 \pm 0.2 \#$ & $0.8 \pm 0.01 \#$ & $1.0 \pm 0.2 \#$ \\
ACTH (ng/l per min) & $2.5 \pm 0.4$ & $4.8 \pm 0.4 \#$ & $3.6 \pm 0.5^{*}$ & $3.1 \pm 0.3^{*}$ \\
Cortisol (nmol/l per min) & $36 \pm 4.4$ & $55 \pm 2.2 \#$ & $41 \pm 3.6^{*}$ & $36 \pm 3.1^{*}$ \\
\hline
\end{tabular}

${ }^{\star} P<0.05$ vs Saline; \#P<0.05 vs Basal.

of somatotroph secretion with an increase in pulse mass without any change in mean interpulse interval or pulse frequency $(12,15,38)$. Subcutaneous GHRP-2 delivery and oral administration of nonpeptidyl GHS likewise augmented 24-h GH secretion by increasing $\mathrm{GH}$ pulse amplitude without any change in pulse duration, interpulse interval, frequency and half-life $(14,15,20)$. However, an increase in pulse frequency has been reported in one other analysis (23).

The present investigation highlights the stimulatory impact of two or three daily acute s.c. injections of a peptidyl GHS on 24-h GH pulsatility. First, our results show that intermittent HEX treatment increases 24-h GH secretion by three- to fourfold in normal young subjects, which is comparable to responses achieved by 24-h continuous i.v. infusion of GHRP-2 (15) or single daily oral administration of MK-0677 (20). The increase in daily GH secretion driven by HEX treatment primarily reflected augmented burst mass (see above) and a small (4-5 min) increase in $\mathrm{GH}$ half-life. The latter change probably reflects the concentration dependence of GH kinetics (17). Based on kinetics principles, the rise in 24-h integrated serum GH concentrations was due predominantly $(>85 \%)$ to increased GH secretion (39).

The elevation of GH ApEn values is consistent with more disorderly patterns of 24-h GH release, as observed during fixed i.v. infusions of GHRH and GHRP-2 $(15,38,40)$ and in healthy pubertal girls (41) and boys $(41,42)$. Aromatizable androgens and oestrogens also elevate GH ApEn $(42,43)$.

The magnitude of the effects of HEX on 24-h GH secretion was essentially equivalent whether two or three injections were administered, although the peak $\mathrm{GH}$ response to three consecutive s.c. injections was reduced. These results indicate that, at least under acute conditions, twice daily stimulation with a peptidyl GHS is sufficient to drive marked somatotroph secretion in young men, and that no further augmentation can be obtained by increasing the frequency of administration. Whether stimulation is maintained with more extended treatment, as observed for continuous s.c. GHRP-2 infusion (12), remains to be established.

At the end of the 24-h profile, the GH response to acute i.v. administration of the peptidyl GHS was blunted independently of the number of previous s.c. injections. Previous studies with continuous infusion $(23,28)$ or prolonged s.c. administration of GHSs (44) showed that the GH response to a following acute challenge with GHS is reduced, reflecting homologous desensitization. As we did not test subjects with stimuli other than acute i.v. HEX at the end of 24-h sessions, we cannot definitely rule out the possibility that reduction of the $\mathrm{GH}$ response to an acute bolus of the hexapeptide reflects some depletion of the GH-releasable pool after two or three s.c. HEX administrations in the previous $24 \mathrm{~h}$. Interestingly, the response attenuation was comparable for two and three injections, thus not establishing a frequency dependence for this effect. However, in another study in elderly subjects, the attenuation of the $\mathrm{GH}$ response to HEX, during chronic treatment with the hexapeptide was found to be correlated with the duration of the treatment (44).

Unlike single oral administration of MK-0677 (20) and continuous 24-h i.v. infusion of peptidyl GHS (23), the present study showed no change in circulating total IGF-I levels after HEX injection, despite effective stimulation of daily somatotroph secretion. This finding agrees with the results of Rahim et al. (44) who reported that even after 16 weeks of s.c. injection of HEX, serum IGF-I (and IGF-binding protein-3) levels did not change significantly. The basis of this disparity is not known, but could reflect differences in the secretagogue type or delivery mode and/or the populations studied.

According to studies performed either with a single and protracted oral administration of MK-0677 (20, 31 ) or with a prolonged treatment with HEX administered subcutaneously once a day (45), HEX did not alter daily lactotroph or corticotroph secretion. In contrast, the acute PRL, ACTH and cortisol responses to i.v. HEX at the end of the 24-h control profiles confirmed an immediate stimulatory activity of GHS on lactotroph and corticotroph secretion $(5,6,9)$. Moreover, in the present study, 24-h HEX treatment eliminated subsequent acute ACTH and cortisol responses to the same hexapeptide. Down-regulation of ACTH responsiveness was selective, since the acute PRL response was fully preserved. In fact, lactotroph secretion can be slightly enhanced by longer-term GHS administration $(46,47)$. 
316 M Maccario and others

EUROPEAN JOURNAL OF ENDOCRINOLOGY (2002) 146

Saline
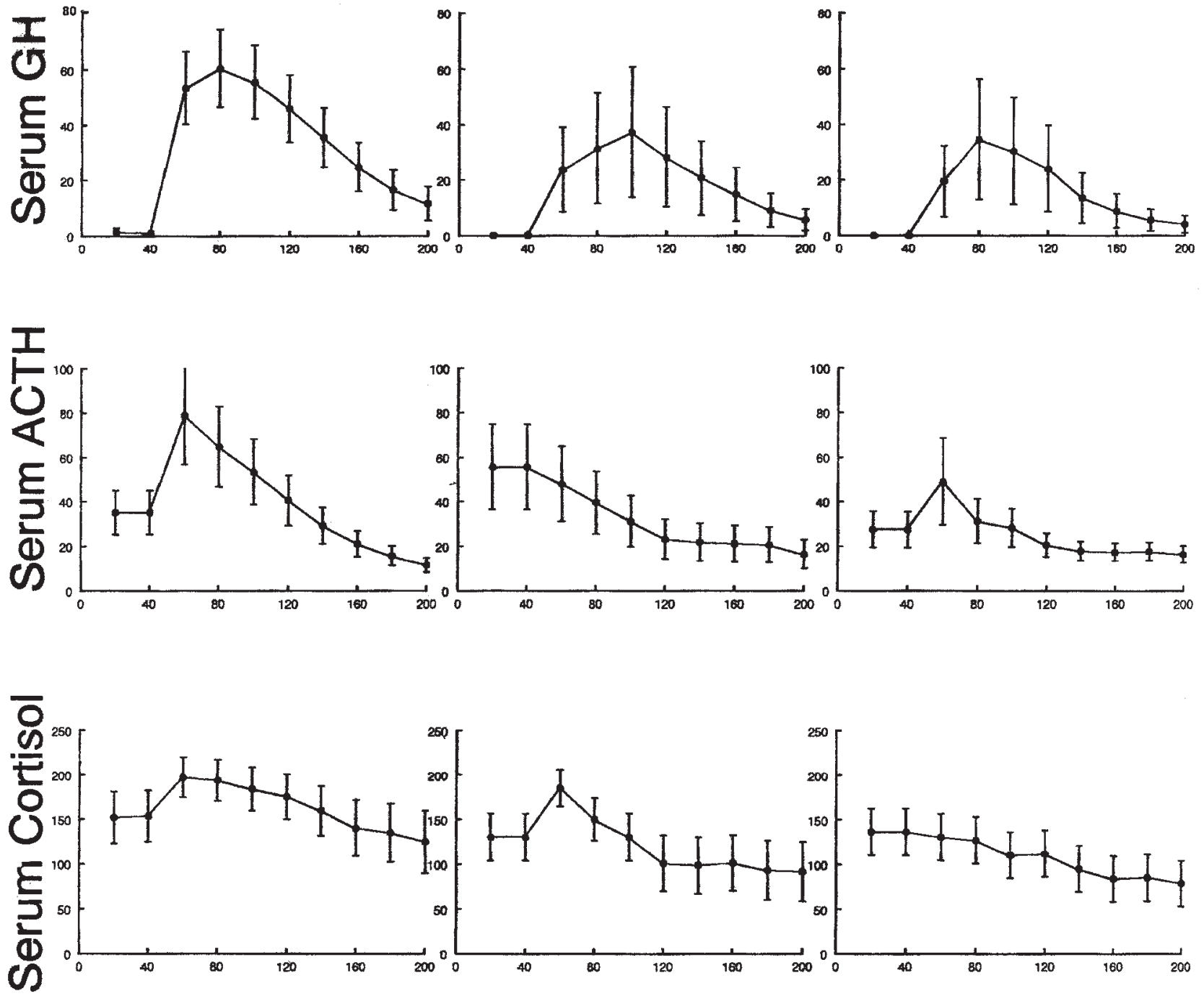

을
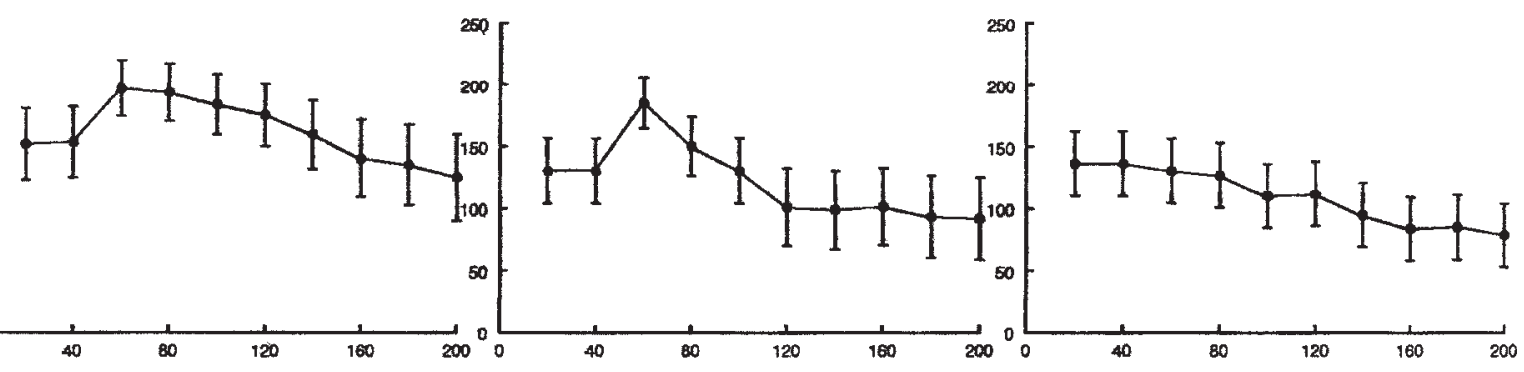

Time (min)

Figure 3 Hormone responses to an acute iv. challenge with $1 \mu \mathrm{g} / \mathrm{kg}$ HEX after each 24-h session in normal volunteers. GH, PRL and cortisol levels are reported in $\mu \mathrm{g} / \mathrm{l}, \mathrm{ACTH}$ in $\mathrm{ng} / \mathrm{l}$. Values are means \pm S.E.M..

www.eje.org

Downloaded from Bioscientifica.com at 04/25/2023 11:37:36 PM

via free access 
In conclusion, the present clinical investigation revealed that two or three daily s.c. injections of HEX increase 24-h GH secretion to an equivalent degree in healthy young men without altering concomitant lactotroph and corticotroph secretion. This dosing schedule blunts subsequent acute $\mathrm{GH}$ and abolishes delayed ACTH (but not PRL) responsiveness to an i.v. dose of the same hexapeptide. HEX selectively augments $\mathrm{GH}$ pulse mass and increases the irregularity of the $\mathrm{GH}$ secretory process but does not increase circulating IGF-I levels.

\section{Acknowledgements}

This study was supported by MURST (grant no. 9906153187), NIH General Clinical Research Centre, NIH RO1 AG 14799, CNR and SMEM Foundation and Europeptides. The authors wish to thank Professor Franco Camanni for his support. The skilful technical assistance of Dr A Bertagna, Mrs A Barberis and Mrs M Taliano is also acknowledged.

\section{References}

1 Arvat E, Maccario M, Di Vito L, Broglio F, Benso A, Gottero C et al. Endocrine activities of ghrelin, a natural GH secretagogue, in humans: a comparison with hexarelin, a non-natural peptidyl GHS, and GH-releasing hormone. Journal of Clinical Endocrinology and Metabolism 200186 1169-1174.

2 Muller EE, Locatelli V \& Cocchi D. Neuroendocrine control of growth hormone secretion. Physiological Reviews 199979 511-607.

3 Giustina A \& Veldhuis JD. Pathophysiology of the neuroregulation of growth hormone secretion in experimental animals and the human. Endocrine Reviews $199819717-797$.

4 Kojima M, Hosoda H, Date Y, Nakazato M, Matsuo H \& Kangawa $\mathrm{K}$. Ghrelin is a growth-hormone-releasing acylated peptide from stomach. Nature $1999 \mathbf{4 0 2} 656-660$.

5 Ghigo E, Arvat E, Broglio F, Giordano R, Gianotti L, Muccioli G et al. Endocrine and non-endocrine activities of growth hormone secretagogues in humans. Hormone Research 199951 9-15.

6 Smith RG, Van der Ploeg LH, Howard AD, Feighner SD, Cheng K, Hickey GJ et al. Peptidomimetic regulation of growth hormone secretion. Endocrine Reviews 199718 621-645.

7 Arvat E, Di Vito L, Broglio F, Papotti M, Muccioli G, Dieguez C et al. Preliminary evidence that Ghrelin, the natural GH secretagogue (GHS)-receptor ligand, strongly stimulates GH secretion in humans. Journal of Endocrinological Investigation 200023 493-495.

8 Date Y, Murakami N, Kojima M, Kuroiwa T, Matsukura S, Kangawa $\mathrm{K}$ et al. Central effects of a novel acylated peptide, ghrelin, on growth hormone release in rats. Biochemical and Biophysical Research Communications 2000275 477-480.

9 Ghigo E, Arvat E \& Camanni F. Orally active growth hormone secretagogues: state of the art and clinical perspectives. Annals of Medicine 199830 159-168.

10 Thorner MO, Chapman IM, Gaylinn BD, Pezzoli SS \& Hartman ML. Growth hormone-releasing hormone and growth hormonereleasing peptide as therapeutic agents to enhance growth hormone secretion in disease and aging. Recent Progress in Hormone Research 199752 215-244.

11 Ghigo E, Arvat E, Aimaretti G, Broglio F, Giordano R \& Camanni F. Diagnostic and therapeutic uses of growth hormone-releasing substances in adult and elderly subjects. Bailliere's Clinical Endocrinology and Metabolism 199812 341-358.

12 Bowers CY, Granda-Ayala R, Parulkar A, Anand M, Baker V \& Reynolds GA. Impact of GHRP-2 infusion for 30-90 days in older men and women with decreased GH secretion. Proceedings of the 81st Annual Endocrine Society Meeting, San Diego, CA, USA 1999 Abstract 12.

13 Merriam GR, Buchner DM, Prinz PN, Schwartz RS \& Vitiello MV. Potential applications of GH secretagogs in the evaluation and treatment of the age-related decline in growth hormone secretion. Endocrine 1997 7 49-52.

14 Jaffe CA, Ho PJ, Demott-Friberg R, Bowers CY \& Barkan AL. Effects of a prolonged growth hormone (GH)-releasing peptide infusion on pulsatile $\mathrm{GH}$ secretion in normal men. Journal of Clinical Endocrinology and Metabolism 199377 1641-1647.

15 Shah N, Evans WS, Bowers CY \& Veldhuis JD. Tripartite neuroendocrine activation of the human growth hormone (GH) axis in women by continuous 24-hour GH-releasing peptide infusion: pulsatile, entropic, and nyctohemeral mechanisms. Clinical Endocrinology 199984 2140-2150.

16 Arvat E, Camanni F \& Ghigo E. Age-related growth hormonereleasing activity of growth hormone secretagogues in humans. Acta Paediatrica 1997423 (Suppl) 92-96.

17 Deghenghi R, Arvat E, Broglio F, Giordano R \& Ghigo E. Agerelated variations in the growth hormone response to growth hormone secretagogues. The Aging Male 19981 234-243.

18 Chapman IM, Hartman ML, Pezzoli SS \& Thorner MO. Enhancement of pulsatile growth hormone secretion by continuous infusion of a growth hormone-releasing peptide mimetic, L-692,429, in older adults - a clinical research center study. Journal of Clinical Endocrinology and Metabolism $1996812874-2880$.

19 Ghigo E, Arvat E, Gianotti L, Grottoli S, Rizzi G, Ceda GP et al. Short-term administration of intranasal or oral hexarelin, a synthetic hexapeptide, does not desensitize the growth hormone responsiveness in human aging. European Journal of Endocrinology $1996135407-412$.

20 Chapman IM, Bach MA, Van Cauter E, Farmer M, Krupa D, Taylor AM et al. Stimulation of the growth hormone $(\mathrm{GH})$-insulin-like growth factor I axis by daily oral administration of a GH secretogogue (MK-677) in healthy elderly subjects. Journal of Clinical Endocrinology and Metabolism 199681 4249-4257.

21 Copinschi G, Leproult R, Van Onderbergen A, Caufriez A, Cole KY, Schilling LM et al. Prolonged oral treatment with MK-677, a novel growth hormone secretagogue, improves sleep quality in man. Neuroendocrinology $199766278-286$.

22 Nijland EA, Strasburger CJ, Popp-Snijders C, van der Wal PS \& van der Veen EA. A five day treatment with daily subcutaneous injections of growth hormone-releasing peptide- 2 causes response attenuation and does not stimulate insulin-like growth factor-I secretion in healthy young men. European Journal of Endocrinology $1998139395-401$.

23 Huhn WC, Hartman ML, Pezzoli SS \& Thorner MO. Twenty-fourhour growth hormone (GH)-releasing peptide (GHRP) infusion enhances pulsatile GH secretion and specifically attenuates the response to a subsequent GHRP bolus. Journal of Clinical Endocrinology and Metabolism 199376 1202-1208.

24 Bowers CY, Sartor AO, Reynolds GA \& Badger TM. On the actions of the growth hormone-releasing hexapeptide, GHRP. Endocrinology $1991 \mathbf{1 2 8} 2027-2035$.

25 Cheng K, Chan WW, Barreto A Jr, Convey EM \& Smith RG. The synergistic effects of His-D-Trp-Ala-Trp-D-Phe-Lys- $\mathrm{NH}_{2}$ on growth hormone (GH)-releasing factor-stimulated $\mathrm{GH}$ release and intracellular adenosine $3^{\prime}, 5^{\prime}$-monophosphate accumulation in rat primary pituitary cell culture. Endocrinology $1989 \mathbf{1 2 4}$ 2791-2798.

26 Badger TM, Millard WJ, McCormick GF, Bowers CY \& Martin JB. The effects of growth hormone $(\mathrm{GH})$-releasing peptides on $\mathrm{GH}$ secretion in perifused pituitary cells of adult male rats. Endocrinology $19841151432-1438$.

27 Clark RG, Carlsson MS, Trojnar J \& Robinson IC. The effects of a growth hormone-releasing peptide and growth hormone- 
releasing factor in conscious and anaesthetized rats. Journal of Neuroendocrinology $19891249-255$.

28 DeBell WK, Pezzoli SS \& Thorner MO. Growth hormone (GH) secretion during continuous infusion of GH-releasing peptide: partial response attenuation. Journal of Clinical Endocrinology and Metabolism 199172 1312-1316.

29 Ghigo E, Arvat E, Bellone J, Ramunni J \& Camanni F. Neurotransmitter control of growth hormone secretion in humans. Journal of Pediatric Endocrinology 19936 263-266.

30 Ghigo E, Arvat E, Rizzi G, Goffi S, Grottoli S, Mucci M et al. Growth hormone-releasing activity of growth hormone-releasing peptide- 6 is maintained after short-term oral pretreatment with the hexapeptide in normal aging. European Journal of Endocrinology 1994131 499-503.

31 Jacks T, Smith R, Judith F, Schleim K, Frazier E, Chen H et al. MK-0677, a potent, novel, orally active growth hormone $(\mathrm{GH})$ secretagogue: $\mathrm{GH}$, insulin-like growth factor I, and other hormonal responses in beagles. Endocrinology $1996 \mathbf{1 3 7}$ 5284-5289.

32 Copinschi G, Van Onderbergen A, L’Hermite-Baleriaux M, Mendel CM, Caufriez A, Leproult R et al. Effects of a 7-day treatment with a novel, orally active, growth hormone (GH) secretagogue, MK-677, on 24-hour GH profiles, insulin-like growth factor I, and adrenocortical function in normal young men (see comments). Journal of Clinical Endocrinology and Metabolism $1996812776-2782$.

33 Sartorio A, De Nicolao G, Pizzini G \& Liberati D. Nonparametric deconvolution provides an objective assessment of $\mathrm{GH}$ responsiveness to $\mathrm{GH}-$ releasing stimuli in normal subjects (see comments). Clinical Endocrinology 199746 387-395.

34 Pincus SM \& Keefe DL. Quantification of hormone pulsatility via an approximate entropy algorithm. American Journal of Physiology 1992262 E741-E754

35 Veldhuis JD \& Pincus SM. Orderliness of hormone release patterns: a complementary measure to conventional pulsatile and circadian analyses (comment). European Journal of Endocrinology $1998138358-362$.

36 Veldhuis JD, Carlson ML \& Johnson ML. The pituitary gland secretes in bursts: appraising the nature of glandular secretory impulses by simultaneous multiple-parameter deconvolution of plasma hormone concentrations. PNAS $1987 \mathbf{8 4}$ $7686-7690$.

37 Friend K, Iranmanesh A \& Veldhuis JD. The orderliness of the growth hormone $(\mathrm{GH})$ release process and the mean mass of GH secreted per burst are highly conserved in individual men on successive days. Journal of Clinical Endocrinology and Metabolism $1996813746-3753$.

38 Shah N, Evans WS, Bowers CY \& Veldhuis JD. Oral estradiol administration modulates continuous intravenous growth hormone $(\mathrm{GH})$-releasing peptide-2-driven $\mathrm{GH}$ secretion in postmenopausal women. Journal of Clinical Endocrinology and Metabolism 200085 2649-2659.

39 Veldhuis JD, Lassiter AE \& Johnson ML. Operating behavior of dual or multiple endocrine pulse generators. American Journal of Physiology 1990259 E351-E361.

40 Iranmanesh A, South S, Liem AY, Clemmons D, Thorner MO, Weltman A et al. Unequal impact of age, percentage body fat, and serum testosterone concentrations on the somatotrophic, IGF-I, and IGF-binding protein responses to a threeday intravenous growth hormone-releasing hormone pulsatile infusion in men. European Journal of Endocrinology 1998139 $59-71$.

41 Veldhuis JD, Roemmich JN \& Rogol AD. Gender and sexual maturation-dependent contrasts in the neuroregulation of growth hormone secretion in prepubertal and late adolescent males and females - a general clinical research center-based study. Journal of Clinical Endocrinology and Metabolism $2000 \mathbf{8 5}$ 2385-2394.

42 Veldhuis JD, Metzger DL, Martha PM Jr, Mauras N, Kerrigan JR, Keenan B et al. Estrogen and testosterone, but not a nonaromatizable androgen, direct network integration of the hypothalamosomatotrope (growth hormone)-insulin-like growth factor I axis in the human: evidence from pubertal pathophysiology and sex-steroid hormone replacement. Journal of Clinical Endocrinology and Metabolism 199782 3414-3420.

43 Pincus SM, Gevers EF, Robinson IC, van den Berg G, Roelfsema F, Hartman ML et al. Females secrete growth hormone with more process irregularity than males in both humans and rats. American Journal of Physiology 1996270 E107-E115.

44 Rahim A, O'Neill PA \& Shalet SM. Growth hormone status during long-term hexarelin therapy. Journal of Clinical Endocrinology and Metabolism 199883 1644-1649.

45 Rahim A, O'Neill PA \& Shalet SM. The effect of chronic hexarelin administration on the pituitary-adrenal axis and prolactin. Clinical Endocrinology 199950 77-84.

46 Ghigo E, Arvat E \& Camanni F. Growth hormone secretagogues as corticotrophin-releasing factors. Growth Hormone and IGF Research 19988 145-148.

47 Bowers CY, Veeraragavan K \& Sethumadhavan K. Atypical growth hormone releasing peptides. In Growth Hormone II. Basic and Clinical Aspects, pp 203-222. Eds BB Bercu \& RF Walker. New York: Springer Verlag, 1993.

Received 9 July 2001

Accepted 9 November 2001 